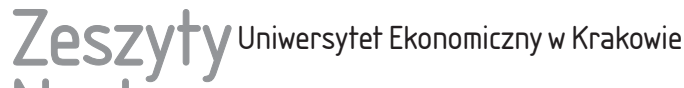 Naukowe
}

$7(955)$

ISSN 1898-6447

Zesz. Nauk. UEK, 2016; 7 (955): 5-22

DOI: 10.15678/ZNUEK.2016.0955.0701

\section{Metodyczne aspekty oceny orientacji przedsiębiorczej w organizacji ${ }^{*}$}

\section{Streszczenie}

W opracowaniu ukazano metodyczne aspekty oceny orientacji przedsiębiorczej w organizacji. Wskazano założenia i istotę koncepcji orientacji przedsiębiorczej oraz wyróżniono i scharakteryzowano jej komponenty: innowacyjność, proaktywność, podejmowanie ryzyka, autonomię i agresywną konkurencyjność. Przedstawiono założenia, narzędzia i problemy pomiaru orientacji przedsiębiorczej w organizacji. Na podstawie przeglądu zagranicznej literatury przedmiotu ukazano rezultaty wieloaspektowych badań w zakresie kształtowania relacji pomiędzy orientacją przedsiębiorczą a wynikami organizacji. Wskazano na potrzebę szerokiej perspektywy rozpatrywania badanej relacji oraz zaakcentowano znaczenie zasobów niematerialnych w kontekście rozwoju dynamicznych zdolności organizacji.

Słowa kluczowe: przedsiębiorczość organizacyjna, orientacja przedsiębiorcza, pomiar orientacji przedsiębiorczej, relacja orientacja przedsiębiorcza-wyniki organizacji.

Klasyfikacja JEL: L26.

Angelika Wodecka-Hyjek, Uniwersytet Ekonomiczny w Krakowie, Katedra Metod Organizacji i Zarządzania, 31-510 Kraków, ul. Rakowicka 27, e-mail: wodeckaa@uek.krakow.pl

* Artykuł powstał w ramach realizacji tematu badawczego pt. „Współczesne koncepcje i metody zarządzania” finansowanego ze środków przyznanych Wydziałowi Zarządzania Uniwersytetu Ekonomicznego w Krakowie w ramach dotacji na utrzymanie potencjału badawczego. 


\section{Wprowadzenie}

Współcześnie przedsiębiorczość odgrywa istotną rolę w rozwoju gospodarczym i społecznym każdego kraju oraz nowoczesnej organizacji. M. Bratnicki uważa, że można mówić o trzech ogólnych podejściach do przedsiębiorczości. Pierwsze uwypukla rolę podmiotu działalności przedsiębiorczej, drugie podkreśla proces realizowania nowych przedsięwzięć, trzecie natomiast tworzenie i wykorzystywanie szans. Ostatnie z nich jest szczególnie przydatne do rozważań o procesach przedsiębiorczości na poziomie organizacji [Bratnicki 2008, s. 17]. Istotą przedsiębiorczości organizacyjnej jest strategiczne ukierunkowanie na rozwój, podejmowanie wyważonego ryzyka, tolerancja nieokreśloności, uczenie się na porażkach, promowanie elastyczności, twórczości, innowacji oraz odnowy i dzięki temu jest ona swoistą strategią działania [Bratnicki i Kulikowska 2009, s. 130], natomiast jej moc sprawczą stanowi orientacja przedsiębiorcza [Dess i Lumpkin 2005, s. 147]. Orientacja przedsiębiorcza postrzegana jest jako podstawa rozwoju i sukcesu firmy, stanowi przewodnik podejmowania przedsiębiorczych działań oraz poszukiwania i wykorzystywania szans. Jest koncepcją związaną z zarządzaniem strategicznym, a jej istota polega na wykorzystywaniu metod, praktyk i sposobów podejmowania decyzji, które pomagają kadrze zarządzającej w dynamicznym procesie tworzenia nowości [Lumpkin i Dess 1996, s. 136]. Dotychczasowe badania nad konceptualizacją orientacji przedsiębiorczej wskazują, że stanowi ona konstrukt wielowymiarowy, a jej składowe mogą występować w różnych kombinacjach oraz zmieniać się niezależnie od siebie. Ponadto mogą one wpływać w różny sposób na inne zmienne [Kreiser, Marino i Weaver 2002, s. 75]. Badania w tym zakresie prowadzone są zarówno przez badaczy zagranicznych (zob. m.in. [Miller 1983, Covin i Slevin 1989, Lumpkin i Dess 1996, Wiklund 1999, Lyon, Lumpkin i Dess 2000, Wiklund i Shepherd 2005, Engelen et al. 2014, Anderson et al. 2015]), jak i na gruncie polskim (m.in. [Bratnicki 2008, 2011, Dyduch 2008, Nogalski i Karpacz 2011, Bratnicki i Kulikowska-Pawlak 2011, Głód 2012, Zbierowski 2012]).

Celem artykułu jest ukazanie metodycznego kontekstu oceny orientacji przedsiębiorczej w organizacji. Scharakteryzowano założenia, istotę i komponenty koncepcji, zagadnienia pomiaru konstruktu orientacji przedsiębiorczej oraz znaczenie orientacji przedsiębiorczej w kształtowaniu wyników organizacji. Podstawę wnioskowania stanowił przegląd rezultatów badań opisanych w literaturze przedmiotu.

\section{Koncepcja orientacji przedsiębiorczej}

Orientacja przedsiębiorcza utożsamiana jest z orientacją strategiczną organizacji, stanowiąc kierunek w zakresie działań przedsiębiorczych oraz poszukiwania i wykorzystywania szans, w których rezultacie podejmowane są decyzje 
zmierzające do kreowania nowych procesów, których wytworem stają się innowacje. Orientacja przedsiębiorcza zwykle postrzegana jest jako proces społeczny realizowany przez uczestników organizacji, których innowacyjne, proaktywne i związane z podejmowaniem ryzyka zachowania strategiczne przeobrażają organizację dzięki odważnemu wyjściu poza schematy i praktyki organizacyjne [Bratnicki 2008, s. 20]. W opinii J.G. Covina i D.P. Slevina orientacja przedsiębiorcza stanowi konstrukt na poziomie organizacyjnym, adekwatny do przedsiębiorczości indywidualnej, a atrybutami firmy przedsiębiorczej są podejmowanie ryzyka, wprowadzanie innowacji i aktywność w działaniu. Badacze przedmiotu uważają, że orientacja przedsiębiorcza powinna być szacowana przez pryzmat zakresu, w jakim menedżerowie są skłonni ponosić ryzyko biznesowe, dostrzegają konieczność wprowadzania zmian i innowacji w celu uzyskania przewagi konkurencyjnej oraz agresywnie konkurują z innymi firmami [Covin i Slevin 1989, s. 218]. S.A. Zahra i D.O. Neubaum orientację przedsiębiorczą rozumieją jako sumę radykalnych innowacji, proaktywnych działań strategicznych i podjętego ryzyka $\mathrm{w}$ forsowaniu projektów niepewnych co do rezultatu [1998, s. 124]. Interpretację tę podtrzymują współcześni badacze J.A. Pearce, P. Fritz i P.S. Davis, wskazując, że w ich rozumieniu orientacja przedsiębiorcza stanowi zbiór odrębnych, ale powiązanych ze sobą zachowań, które cechują się innowacyjnością, proaktywnością, konkurencyjną agresywnością, podejmowaniem ryzyka i autonomią [2010, s. 219]. P.M. Kreiser, L.D. Marino i K.M. Weaver [2002] wykazali, iż wczesne konceptualizacje orientacji przedsiębiorczej zorientowane były na poszukiwanie atrybutów kształtowania strategii firm przedsiębiorczych, w odróżnieniu od firm tradycyjnych, kolejne dotyczyły badania wpływu poszczególnych składowych konstruktu na przedsiębiorcze postawy organizacji. W konsekwencji wykazano, iż przedsiębiorcze firmy podejmują ryzyko częściej niż inne organizacje; zależności pomiędzy orientacją przedsiębiorczą a otoczeniem są silniejsze w firmach odnoszących sukcesy; natężenie orientacji przedsiębiorczej określa się poprzez oszacowanie poziomu tworzących ją czynników, jednakże nie oznacza to, że im więcej każdego ze składających się nań elementów, tym wyższa przedsiębiorczość; określony poziom natężenia poszczególnych czynników zależny jest od specyficznej sytuacji danej organizacji [Kreiser, Marino i Weaver 2002, s. 75-77].

\section{Komponenty orientacji przedsiębiorczej}

Podłożem identyfikacji składowych orientacji przedsiębiorczej, w której zasadnicze elementy konstruktu obejmują: innowacyjność, podejmowanie ryzyka i proaktywność, jest koncepcja wprowadzona do literatury przez D. Millera [1983]. 
Innowacyjność odnosi się do zaangażowania w tworzenie nowych produktów, dóbr i usług oraz wprowadzania w życie nowych modeli biznesowych, które opisują, w jaki sposób organizacja projektuje i dokonuje wymiany ekonomicznej, wiążąc zasoby i rynki produktowe w poszukiwaniu zysku [Bratnicki 2008, s. 18]. Rozumiana jest również jako skłonność do eksperymentowania oraz podejmowania działań kreatywnych w celu nie tylko doskonalenia produktów i procesów, lecz również dążenia do wdrażania nowych technologii [Dess i Lumpkin 2005, s. 150]. Proaktywność związana jest z tworzeniem nowych działalności biznesowych dla istniejących lub nowych rynków, rozwijaniem nowych kompetencji i zdolności organizacji oraz utrzymywaniem organizacji w stanie czujności wobec szans, w celu wyprzedzenia konkurencji i szybkiej adaptacji do zmieniających się trendów rynkowych [Dess i Lumpkin 2005, s. 150; Bratnicki 2008, s. 18]. W opinii W. Dyducha błędem jest przypisywanie proaktywności organizacjom, które wykazywały dużą szybkość we wprowadzaniu innowacji, gdyż organizacja charakteryzująca się ukierunkowaniem na nowości, szybkość działania i wychwytywanie nowych trendów niekoniecznie uzyska przewagę konkurencyjną. Proaktywność ma głębszy charakter i należy ją rozważać w odniesieniu do jej przeciwieństwa, czyli pasywności rozumianej jako obojętność wobec szans, nieumiejętność ich poszukiwania i podejmowania. Pod tym względem proaktywność obejmuje zarówno inicjatywy dotyczące kształtowania otoczenia dla własnych korzyści, jak i umiejętność odpowiedzi na wyzwania stawiane przez konkurentów [Dyduch 2008, s. 98-99]. Podejmowanie ryzyka od dawna związane było z przedsiębiorczością, o czym świadczą interpretacje tego pojęcia eksponujące gotowość przedsiębiorców do ponoszenia nakładów związanych z działalnością gospodarczą. J. Wiklund i D. Shepherd zauważają, że firmy charakteryzujące się orientacją przedsiębiorczą często opisywane są poprzez ryzykowne zachowania (angażowanie znacznych ilości zasobów, zaciąganie pożyczek), które podejmowane są w celu osiągnięcia wysokich zwrotów poprzez wykorzystanie szans pojawiających się na rynku [2005, s. 71-91].

Współcześnie akcentowana jest również propozycja G.T. Lumpkina i G.G. Dessa [1996], którzy tradycyjny konstrukt orientacji przedsiębiorczej uzupełnili wymiarem autonomii i konkurencyjnej agresywności. Autonomia dotyczy działań podejmowanych przez członków organizacji lub zespoły powoływane do opracowania nowej koncepcji biznesowej, które zmierzają do realizacji wizji organizacji. Oznacza ona rozpoznawanie szans i ich wykorzystywanie, niezależnie od barier. W przypadku ograniczonej dostępności zasobów czy intensywnych działań konkurencji organizacja zorientowana przedsiębiorczo nie zaniecha autonomicznych procesów związanych z realizacją nowych przedsięwzięć, ponieważ jej członkowie mają swobodę działania 
w podejmowaniu decyzji. Niezależność przywódcy może przejawiać się reprezentowaniem oryginalnej, scentralizowanej wizji, a niezależność pracowników - podejmowaniem zadań o charakterze eksperymentalnym [Dyduch 2008, s. 98]. Konkurencyjna agresywność może być definiowana jako skłonność firm do stawiania wyzwań konkurentom w celu ich wyprzedzenia i osiągnięcia lepszej pozycji na rynku [Lumpkin i Dess 1996, s. 148]. Charakteryzowana jest przez pryzmat reaktywności, która może przybrać formę konfrontacji lub walki konkurencyjnej. Odzwierciedla też umiejętność podejmowania niekonwencjonalnych działań w przeciwieństwie do stosowania tradycyjnych metod konkurowania, do których zaliczyć można: skanowanie otoczenia konkurencyjnego, analizowanie i wykorzystywanie słabości konkurentów, koncentrowanie się na produktach stanowiących wysoką wartość dodaną oraz monitorowanie kosztów [Dyduch 2008, s. 99].

G.G. Dess i G.T. Lumpkin [2005, s. 153], w konsekwencji sformułowanych definicji, doprecyzowali szereg wskazówek dla praktyków chcących stymulować efektywne działania przedsiębiorcze w organizacji. W tabeli 1 przedstawiono najistotniejsze kwestie determinujące rozwój poszczególnych wymiarów orientacji przedsiębiorczej w organizacji.

Tabela 1. Rozwój orientacji przedsiębiorczej w organizacji - problemy do rozważenia

\begin{tabular}{|c|c|}
\hline $\begin{array}{l}\text { Wymiary orientacji } \\
\text { przedsiębiorczej }\end{array}$ & Zagadnienia \\
\hline Innowacyjność & $\begin{array}{l}\text { - Czy firma stosuje rozwiązania pobudzające innowacje produktowe, tech- } \\
\text { nologiczne i organizacyjne? } \\
\text { - W jaki sposób firma stymuluje procesy kreatywności i eksperymentowania? } \\
\text { - Czy firma prawidłowo inwestuje w nowe technologie, B+R oraz } \\
\text { w ciągłe doskonalenie swojej działalności? } \\
\text { - Czy innowacyjne inicjatywy firmy są na tyle oryginalne, że są zbyt } \\
\text { trudne do naśladowania przez konkurencję? } \\
\text { - Czy firma zapobiegawczo inwestuje w badania i rozwój w okresie kry- } \\
\text { zysu, czy wręcz przeciwnie, jest to pierwszy obszar, w którym dokony- } \\
\text { wane są znaczne cięcia kosztów? }\end{array}$ \\
\hline Proaktywność & $\begin{array}{l}\text { - Czy firma stara się być pionierem rozwiązań nowych i innowacyjnych } \\
\text { i czerpać z tego korzyści? } \\
\text { - Czy firma jest gotowa rozwiązywać problemy (np. pokonywać opór } \\
\text { klientów wobec nowości, nieprzewidziane problemy techniczne) oraz } \\
\text { ponosić konsekwencje i koszty związane z pozycją pioniera? } \\
\text { - Czy firma chce efektywnie korzystać z nowoczesnych metod zarządza- } \\
\text { nia, wspierających ciągłą proaktywność? } \\
\text { - Czy firma stale poszukuje możliwości zaoferowania klientom nowych } \\
\text { produktów i usług, aby na bieżąco wyprzedzać konkurencję? }\end{array}$ \\
\hline
\end{tabular}


cd. tabeli 1

\begin{tabular}{|c|c|}
\hline $\begin{array}{l}\text { Wymiary orientacji } \\
\text { przedsiebiorczej }\end{array}$ & Zagadnienia \\
\hline $\begin{array}{l}\text { Podejmowanie } \\
\text { ryzyka }\end{array}$ & $\begin{array}{l}\text { - Czy firma popiera pracowników w podejmowaniu ryzyka w różnych } \\
\text { obszarach, często na poziomie personalnym i zachęca ich do tego? } \\
\text { - Czy firma podejmuje działania związane z minimalizowaniem niepewno- } \\
\text { ści i skutków ryzyka w celu uzyskania lepszej pozycji konkurencyjnej? } \\
\text { - Czy firma wzmacnia swoją pozycję konkurencyjną, podejmując ryzyko } \\
\text { z wykorzystaniem doświadczeń (technik i procesów), które stosowane } \\
\text { były w innych obszarach? } \\
\text { - Czy firma ostrożnie zarządza ryzykiem, unikając podejmowania działań, } \\
\text { które nie zostały wcześniej zaplanowane lub w stosunku do których nie } \\
\text { podjęto stosownych badań? }\end{array}$ \\
\hline Autonomia & $\begin{array}{l}\text { - Czy w firmie powoływane są grupy autonomiczne, których zadaniem jest } \\
\text { opracowywanie oryginalnych rozwiązań metodami twórczego myślenia? } \\
\text { - Czy w przypadku funkcjonowania grup autonomicznych dana firma } \\
\text { zapewnia odpowiednią koordynację działań w celu maksymalizowania } \\
\text { efektów i unikania powielania pomysłów? } \\
\text { - Czy firma właściwie stymuluje prace grup autonomicznych i kieruje tymi } \\
\text { pracami, aby zminimalizować lub eliminować nieudane inicjatywy? } \\
\text { - Czy firma wdrożyła w strukturze organizacyjnej zmiany niezbędne dla } \\
\text { funkcjonowania grup autonomicznych poszukujących nowych pomysłów? } \\
\text { - Czy firma wspiera kulturę innowacyjną poprzez system nagród i motywo- } \\
\text { wania pracowników? } \\
\text { - Czy firma zachęca i pobudza rozwój technologiczny, innowacje produk- } \\
\text { towe i organizacyjne? } \\
\text { - W jaki sposób firma stymuluje kreatywność i eksperymentowanie? } \\
\text { - Czy firma prawidłowo inwestuje w nowe technologie, B+R oraz ciągłe } \\
\text { doskonalenie? } \\
\text { - Czy innowacyjne inicjatywy firmy są trudne do naśladowania przez } \\
\text { konkurencję? } \\
\text { - Czy firma ochronnie inwestuje w badania i rozwój w okresach kryzysu, } \\
\text { czy są one na ogół pierwszym obszarem, w którym dokonywane są } \\
\text { znaczne cięcia? }\end{array}$ \\
\hline $\begin{array}{l}\text { Konkurencyjna } \\
\text { agresywność }\end{array}$ & $\begin{array}{l}\text { - Czy firma efektywnie wykorzystuje agresywną postawę w zwalczaniu } \\
\text { w branży trendów, które mogą zagrażać przetrwaniu lub utrzymaniu } \\
\text { pozycji konkurencyjnej? } \\
\text { - Czy firma dąży do poprawy swojej pozycji, wprowadzając na rynki } \\
\text { produkty po znacznie niższych cenach, kopiując działalności biznesowe } \\
\text { konkurentów? } \\
\text { - Czy firma wie, kiedy znajduje się w niebezpieczeństwie, działając zbyt } \\
\text { agresywnie, i umie unikać takich działań w obawie przed utratą reputacji } \\
\text { lub odwetem konkurencji? }\end{array}$ \\
\hline
\end{tabular}

Źródło: opracowanie własne na podstawie [Dess i Lumpkin 2005, s. 153].

Wskazane atrybuty poszczególnych wymiarów konstruktu orientacji przedsiębiorczej są przedmiotem bieżących analiz badaczy i praktyków zarządzania. 
Szczególnie interesująca wydaje się propozycja rekonceptualizacji konstruktu orientacji przedsiębiorczej zaproponowana przez B.S. Andersona, P.M. Kreisera, D.F. Kuratko i J.S. Hornsby'ego [2015]. Badacze zaproponowali syntetyczne ujęcie struktury konstruktu na poziomie firmy, w którym wyróżnili dwa elementy: zachowania przedsiębiorcze (obejmujące innowacyjność i proaktywność) oraz postawę menedżerską wobec ryzyka (a także skłonność do podejmowania ryzyka). Zdefiniowali oni zachowania przedsiębiorcze jako dążenie do opracowywania nowych produktów, procesów lub modeli biznesowych (rozumianych w kontekście innowacyjności) wraz z ich komercjalizacją w nowych domenach rynków lub produktów (utożsamianych z proaktywnością). Postawę wobec ryzyka uznali za inherentną cechę menedżera wyższego szczebla, niezbędną do rozwoju i wdrożenia strategii firmy, akcentowaną w podejmowaniu działań niepewnych co do rezultatu. Novum podejścia stanowi zamiana trzech kluczowych dotychczas komponentów orientacji przedsiębiorczej na dwa wymiary niższego rzędu. Skłonność do podejmowania ryzyka jest wymiarem warunkowanym postawą lub nastawieniem, podczas gdy innowacyjność i proaktywność składają się na jeden wymiar o charakterze behawioralnym, warunkowany reakcją na bodźce płynące z otoczenia. W związku ze swoją propozycją autorzy twierdzą, że orientacja przedsiębiorcza jest konstruktem wielowymiarowym składającym się z dwóch niejednoznacznych komponentów, istnieje pozytywna korelacja pomiędzy wyróżnionymi komponentami, ponadto zarówno postawa wobec ryzyka, jak i zachowania przedsiębiorcze mają charakter fundamentalny, warunkujący istnienie orientacji przedsiębiorczej w organizacji. Aby można było uznać firmę za przedsiębiorczą, zgodnie z koncepcją autorów, niezbędne są zachowania przedsiębiorcze, ale samoistnie nie są one wystarczające w wymiarze konceptualnym - konieczne jest uwydatnienie skłonności menedżerów do popierania projektów niepewnych co do rezultatu, zwłaszcza w niesprzyjających warunkach otoczenia [Anderson et al. 2015, s. 1582-1583].

\section{Pomiar orientacji przedsiębiorczej}

Próby operacjonalizacji i pomiaru składowych orientacji przedsiębiorczej podejmowane były przez wielu badaczy. D.W. Lyon, G.T. Lumpkin i G.G. Dess wskazali, że konstrukt orientacji przedsiębiorczej w organizacji może być oceniany z perspektywy zarządzających, zachowania firmy oraz oceny alokacji zasobów. Podstawową zaletą prowadzenia badania wśród pracowników firmy jest założenie, że są oni najbardziej wiarygodnym źródłem informacji, a ich opinie oddają rzeczywisty obraz kondycji firmy. Jednakże rezultaty mogą być obciążone stronniczością opinii, ponadto mogą być kosztowne i czasochłonne (w przypadku wywiadów) oraz mogą powodować problemy interpretacyjne. W przypadku badania zachowania firmy podstawę wnioskowania stanowią źródła wtórne, które generalnie nie 
powinny wzbudzać problemów interpretacyjnych, jednak pomiar może być utrudniony w sytuacji, gdy dane są niekompletne lub nadmiernie rozproszone (np. gdy badamy poszczególne oddziały firmy, a baza danych istnieje fizycznie na kilku komputerach) oraz nie obejmują kwestii istotnych. Ocena alokacji zasobów dotyczy analizy wskaźnikowej, której zaletą jest łatwość pozyskiwania danych i prostota interpretacji, wadę stanowi zaś częsta nieadekwatność wyników i słabe powiązanie z celem badawczym [Lyon, Lumpkin i Dess 2000, s. 1064-1065].

Jednym z pierwszych narzędzi pomiaru orientacji przedsiębiorczej był model skali pomiarowej postawy strategicznej zaproponowany przez J.G. Covina i D.P. Slevina w agregatowym narzędziu służącym do pomiaru poziomu zarządzania strategicznego w małych firmach (agregat zawierał także komponenty do pomiaru uwarunkowań otoczenia i struktury organizacyjnej) [1989, s. 85-86]. Narzędzie to, bazujące pierwotnie na dziewięciu pytaniach, zostało uporządkowane w kontekście trzyelementowej struktury konstruktu orientacji przedsiębiorczej obejmującej zagadnienia dotyczące: innowacyjności, proaktywności i podejmowania ryzyka i stało się następnie podstawą konstruowania większości współczesnych narzędzi [Covin i Wales 2012, s. 692] - zob. tabela 2.

Rozwiniętą koncepcję narzędzia pomiaru orientacji przedsiębiorczej, w której uwzględnione zostały również zagadnienia związane z autonomią i agresywną konkurencyjnością, zaproponowali M. Hughes i R.E. Morgan [2007, s. 659]. Badacze ci, zgodnie z koncepcją G.T. Lumpkina i G.G. Dessa [1996, s. 137], wysunęli tezę, że wymiary orientacji przedsiębiorczej mogą się różnić i kształtować niezależnie od siebie, co pozwala badać je oddzielnie i autonomicznie analizować ich efekty i wpływ na rezultaty biznesowe organizacji. W zaproponowanym narzędziu do każdego wymiaru zdefiniowali oni po kilka stwierdzeń i podobnie jak J.G. Covin i D.P. Slevin wykorzystali siedmiopunktową skalę Likerta, zakładając, że 1 oznacza „nie zgadzam się”, a 7 ,zdecydowanie się zgadzam” (tabela 3).

Wykorzystujący pięciopunktową skalę zagregowany zestaw ośmiu pytań diagnozujących poziom orientacji przedsiębiorczej, bazujący na koncepcji J.G. Covina i D.P. Slevina, analogiczny w zakresie istoty i treści, zaproponowali też P.M. Kreiser, L.D. Marino i K.M. Weaver [2002, s. 94]. Skalę tę jako podstawę koncepcji badawczych wykorzystano również w warunkach polskich [Dyduch 2008, Nogalski i Karpacz 2011].

Problematyka właściwej operacjonalizacji i pomiaru orientacji przedsiębiorczej stanowi aktualny przedmiot dyskusji. W. Dyduch na podstawie przeprowadzonej kwerendy rezultatów badań dotyczących pomiaru konstruktu orientacji przedsiębiorczej w latach 1995-2007 zauważył, że najczęściej badanym wymiarem jest innowacyjność, a najczęściej stosowanym sposobem pomiaru tworzenie wskaźników z wykorzystaniem miar dotyczących wielkości wydatków przeznaczanych na badania i rozwój w stosunku do różnych zmiennych [Dyduch 2008, s. 109]. 
Tabela 2. Zmodyfikowane narzędzie do pomiaru orientacji przedsiębiorczej według J.G. Covina i D.P. Slevina

$$
\text { Innowacyjność }
$$

Kadra zarządzająca wyższego szczebla w firmie ogólnie preferuje:

\begin{tabular}{|l|l|l|l|l|l|l|l|l|}
\hline Nacisk na marketing wypróbowa- & 1 & 2 & 3 & 4 & 5 & 6 & 7 & Nacisk na badania i rozwój, techno-
\end{tabular} nych i sprawdzonych produktów lub usług logiczne przywództwo i innowacje

Ile nowych linii produktów lub usług firma wprowadziła na rynek w ciągu ostatnich 5 lat (lub od momentu powstania)?

\begin{tabular}{|l|l|l|l|l|l|l|l|l}
\hline Firma nie wprowadziła nowych & 1 & 2 & 3 & 4 & 5 & 6 & 7 & Firma wprowadziła bardzo wiele
\end{tabular} \begin{tabular}{ll|l|l|l|l|l|l|l|l|l|l} 
linii produktów lub usług & & & & & & nowych linii produktów lub usług
\end{tabular}

$\begin{array}{lllllllllllll}\text { Zmiany w produktach lub usługach } & 1 & 2 & 3 & 4 & 5 & 6 & 7 & \text { Zmiany w produktach lub usługach }\end{array}$ były mało znaczące

\begin{tabular}{|c|c|c|c|c|c|c|c|c|c|}
\hline \multicolumn{10}{|c|}{ Proaktywność } \\
\hline \multicolumn{10}{|l|}{ W stosunkach z konkurentami firma: } \\
\hline $\begin{array}{l}\text { Zazwyczaj odpowiada na działania } \\
\text { zainicjowane przez konkurentów }\end{array}$ & 1 & 2 & 3 & 4 & 5 & & & 7 & $\begin{array}{l}\text { Zazwyczaj sama inicjuje działania, } \\
\text { na które odpowiadają konkurenci }\end{array}$ \\
\hline $\begin{array}{l}\text { Bardzo rzadko jest pierwszą firmą } \\
\text { wprowadzającą nowe produkty/ } \\
\text { usługi, techniki organizacyjne, } \\
\text { technologie wytwarzania etc. }\end{array}$ & 1 & 2 & 3 & 4 & 5 & & 5 & 7 & $\begin{array}{l}\text { Bardzo często jest pierwszą firmą } \\
\text { wprowadzającą nowe produkty/ } \\
\text { usługi, techniki organizacyjne, } \\
\text { technologie wytwarzania etc. }\end{array}$ \\
\hline $\begin{array}{l}\text { Zazwyczaj stara się unikać starć } \\
\text { z konkurentami, preferuje postawę } \\
\text { „żyj i pozwól żyć innym” }\end{array}$ & 1 & 2 & 3 & 4 & 5 & & 5 & 7 & $\begin{array}{l}\text { Zazwyczaj podejmuje rywalizację } \\
\text { z konkurentami, preferuje postawę } \\
\text { „Zwalczać konkurencję” }\end{array}$ \\
\hline \multicolumn{10}{|c|}{ Podejmowanie ryzyka } \\
\hline \multicolumn{10}{|c|}{ Kadra zarządzająca wyższego szczebla w firmie generalnie cechuje się: } \\
\hline $\begin{array}{l}\text { Silną tendencją do realizowania } \\
\text { projektów o niskim poziomie } \\
\text { ryzyka (o normalnej i pewnej } \\
\text { zyskowności) }\end{array}$ & 1 & 2 & 3 & 4 & 5 & & & 7 & $\begin{array}{l}\text { Silną tendencją do podejmowa- } \\
\text { nia projektów o wysokim ryzyku } \\
\text { (z szansą na wysoki poziom } \\
\text { zyskowności) }\end{array}$ \\
\hline \multicolumn{10}{|c|}{ Kadra zarządzająca wyższego szczebla w firmie generalnie wierzy, że: } \\
\hline $\begin{array}{l}\text { Ze względu na naturę otoczenia } \\
\text { najlepsze jest działanie ostrożne } \\
\text { i stopniowe }\end{array}$ & 1 & 2 & 3 & 4 & 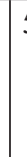 & & & 7 & $\begin{array}{l}\text { Ze względu na naturę otoczenia } \\
\text { najlepsze jest działanie odważne } \\
\text { i śmiałe o szerokim zakresie, nie- } \\
\text { zbędne do osiągnięcia celów firmy }\end{array}$ \\
\hline \multicolumn{10}{|c|}{ W warunkach podejmowania decyzji w niepewności firma: } \\
\hline $\begin{array}{l}\text { Zazwyczaj adaptuje się do sytu- } \\
\text { acji, przyjmując postawę ,czekam } \\
\text { i obserwuję”, aby zminimalizować } \\
\text { koszty decyzji }\end{array}$ & 1 & 2 & 3 & 4 & 5 & & & 7 & $\begin{array}{l}\text { Zazwyczaj adaptuje się śmiało } \\
\text { i odważnie, przyjmując postawę } \\
\text { agresywną w celu wykorzystania } \\
\text { możliwości }\end{array}$ \\
\hline
\end{tabular}

Źródło: [Covin i Wales 2012, s. 692], tłum. aut. 
Tabela 3. Narzędzie do pomiaru orientacji przedsiębiorczej według M. Hughesa i R.E. Morgana

\begin{tabular}{|c|c|c|c|c|c|c|c|}
\hline \multicolumn{8}{|l|}{ Podejmowanie ryzyka } \\
\hline $\begin{array}{l}\text { Termin ,podejmujący ryzyko” jest pozytywnym atrybutem pracow- } \\
\text { nika naszej firmy }\end{array}$ & 1 & 2 & 3 & 4 & 5 & 6 & 7 \\
\hline $\begin{array}{l}\text { Pracownicy naszej firmy są zachęcani do podejmowania ryzyka wraz } \\
\text { z nowymi pomysłami }\end{array}$ & 1 & 2 & 3 & 4 & 5 & 6 & 7 \\
\hline $\begin{array}{l}\text { Nasza firma kładzie nacisk zarówno na poszukiwanie możliwości, jak } \\
\text { i na eksperymentowanie }\end{array}$ & 1 & 2 & 3 & 4 & 5 & 6 & 7 \\
\hline \multicolumn{8}{|l|}{ Innowacyjność } \\
\hline Aktywnie wprowadzamy usprawnienia i innowacje w naszej branży & 1 & 2 & 3 & 4 & 5 & 6 & 7 \\
\hline Nasza firma jest kreatywna pod względem metod działania & 1 & 2 & 3 & 4 & 5 & 6 & 7 \\
\hline Nasza firma poszukuje nowych sposobów działania i wytwarzania & 1 & 2 & 3 & 4 & 5 & 6 & 7 \\
\hline \multicolumn{8}{|l|}{ Proaktywność } \\
\hline $\begin{array}{l}\text { Zawsze staramy się przejąć inicjatywę w każdej sytuacji (np. w sto- } \\
\text { sunku do konkurentów, w projektach, kiedy pracujemy z innymi) }\end{array}$ & 1 & 2 & 3 & 4 & 5 & 6 & 7 \\
\hline Nasza firma identyfikuje możliwości i poszukuje ich & 1 & 2 & 3 & 4 & 5 & 6 & 7 \\
\hline $\begin{array}{l}\text { Nasza firma podejmuje się działań, na które inne organizacje nie } \\
\text { reagują }\end{array}$ & 1 & 2 & 3 & 4 & 5 & 6 & 7 \\
\hline \multicolumn{8}{|l|}{ Konkurencyjna agresywność } \\
\hline Nasza firma jest niezwykle konkurencyjna & 1 & 2 & 3 & 4 & 5 & 6 & 7 \\
\hline $\begin{array}{l}\text { Generalnie nasza firma przyjmuje odważną i agresywną postawę } \\
\text { wobec konkurencji }\end{array}$ & 1 & 2 & 3 & 4 & 5 & 6 & 7 \\
\hline $\begin{array}{l}\text { Nasza firma stara się powstrzymywać działania konkurencji i umiejęt- } \\
\text { nie nimi manewrować }\end{array}$ & 1 & 2 & 3 & 4 & 5 & 6 & 7 \\
\hline \multicolumn{8}{|l|}{ Autonomia } \\
\hline Pracownicy mają prawo myśleć i działać niezależnie & 1 & 2 & 3 & 4 & 5 & 6 & 7 \\
\hline $\begin{array}{l}\text { Pracownicy wykonują zadania, w których realizacji mogą inicjować } \\
\text { i wprowadzać zmiany }\end{array}$ & 1 & 2 & 3 & 4 & 5 & 6 & 7 \\
\hline $\begin{array}{l}\text { Pracownicy otrzymują swobodę i niezależność w podejmowaniu decy- } \\
\text { zji co do swojej pracy }\end{array}$ & 1 & 2 & 3 & 4 & 5 & 6 & 7 \\
\hline Pracownicy otrzymują swobodę w zakresie komunikowania się & 1 & 2 & 3 & 4 & 5 & 6 & 7 \\
\hline $\begin{array}{l}\text { Pracownicy otrzymują uprawnienia do podejmowania samodzielnych } \\
\text { decyzji w zakresie działań, które uważają za zgodne z interesem firmy } \\
\text { - samodzielnie też są za nie odpowiedzialni }\end{array}$ & 1 & 2 & 3 & 4 & 5 & 6 & 7 \\
\hline Pracownicy mają dostęp do wszystkich istotnych informacji & 1 & 2 & 3 & 4 & 5 & 6 & 7 \\
\hline
\end{tabular}

Źródło: opracowanie własne na podstawie [Hughes i Morgan 2007, s. 659].

Aktualnie konstruowane są coraz nowsze narzędzia (oparte na modelach wykorzystujących wskaźniki reflektywne lub formatywne), których istota 
powinna odzwierciedlać specyfikę funkcjonowania organizacji i zamierzony cel badawczy, a problem spójnej interpretacji wyników tkwi w tym, iż dla każdego badacza konstrukt ten może oznaczać co innego [Covin i Wales 2012, s. 698].

\section{Orientacja przedsiębiorcza a wyniki organizacji}

Jedną z perspektyw badania orientacji przedsiębiorczej jest ukazanie jej wpływu na wyniki organizacji (ang. performance). Należy wyjaśnić znaczenie tego terminu, który w odniesieniu do zarządzania często jest różnie interpretowany. Słowo performance zgodnie ze słownikiem angielsko-polskim oznacza m.in. wykonanie, osiągnięcie, wywiązanie się. W opinii B. Ziębickiego najczęściej rozumiane jest ono jako osiągane wyniki, czyli osiągnięcia pracowników, zespołów lub organizacji jako całości. Wyniki w ramach organizacji mogą przybierać różną postać i być następstwem różnych czynników. $Z$ tego względu termin performance $\mathrm{w}$ odniesieniu do organizacji powinien być zawsze rozpatrywany w powiązaniu z jej celami, satysfakcją interesariuszy oraz kondycją ekonomiczną [Ziębicki 2011, s. 94]. Pionierskie badania w tym zakresie przedstawili G.T. Lumpkin i G.G. Dess [1996], stawiając tezę, że innowacyjność, proaktywność, podejmowanie ryzyka, autonomia i konkurencyjna agresywność są podwymiarami orientacji przedsiębiorczej i mogą zmieniać się niezależnie od siebie. Ponadto mogą wpływać w różny sposób na zmienne, w tym na wyniki organizacji [Lumpkin i Dess 1996, s. 142]. W zaproponowanym modelu autorzy uwypuklili istotę podejścia sytuacyjnego, które zakłada konieczność uwzględnienia wpływu zarówno czynników otoczenia, jak i czynników organizacyjnych na proces relacji pomiędzy orientacją przedsiębiorczą a wynikami (rys. 1).

Wskazana teza stała się przedmiotem wieloaspektowych analiz prowadzonych w obszarze przedsiębiorstw (zwłaszcza MŚP) przez współczesnych badaczy, którzy w głównej mierze wykazywali pozytywną zależność pomiędzy starannie skomponowanym konstruktem orientacji przedsiębiorczej a wynikami uzyskiwanymi przez organizację. Uzasadnili również, że zależność ta warunkowana jest różnorodnymi zmiennymi o charakterze zależnym, niezależnym i moderującym. Interesującego przeglądu dorobku w tym zakresie dokonali niemieccy badacze A. Engelen, H. Kube, S. Schmidt i T.Ch. Flatten [2014]. Istotę prowadzonych badań stanowiło wykazanie związku pomiędzy wynikami organizacji a jej determinantami w warunkach istnienia zmiennych wpływających na tę zależność. Zmienną zależną stanowiły wyniki organizacji (performance), natomiast orientacja przedsiębiorcza, w zależności od przyjętego kontekstu badania, pełniła 
funkcję zmiennej niezależnej lub moderującej¹. Szczegółowy rezultat prowadzonych analiz prezentuje rys. 2 .

Wnioskowanie badaczy w zakresie prowadzonych analiz obejmuje dwa okresy: lata 80. i 90. dwudziestego stulecia oraz okres współczesny, dotyczący badań prowadzonych po roku 2000.

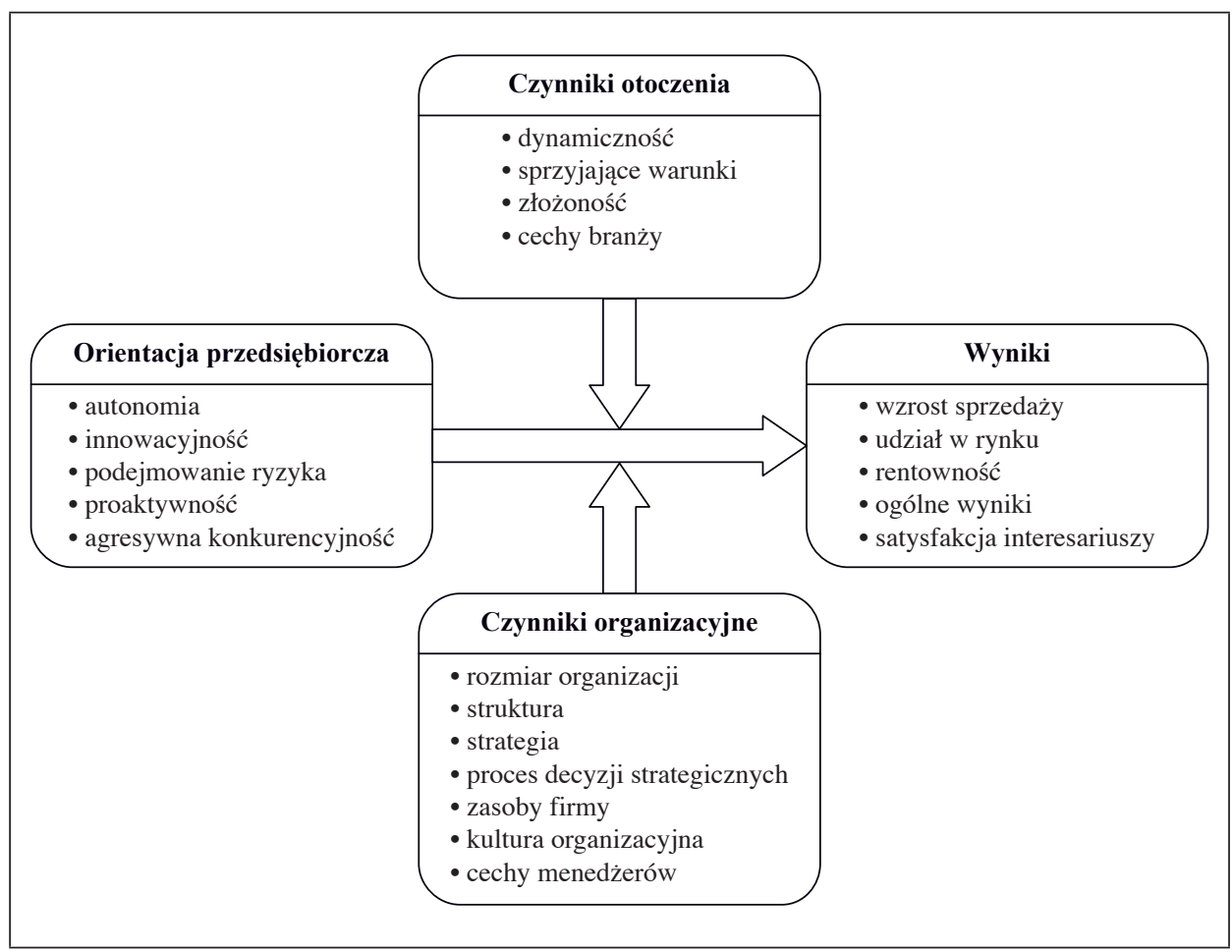

Rys. 1. Konceptualny model orientacji przedsiębiorczej w relacji do wyników organizacji

Źródło: [Lumpkin i Dess 1996, s. 152].

${ }^{1}$ Moderacja występuje wówczas, gdy wpływ zmiennej niezależnej $(X)$ na zmienną zależną $(Y)$ różni się w zależności od poziomu trzeciej zmiennej $(Z)$, zwanej zmienną regulującą (moderującą), która współdziała ze zmienną niezależną. Moderatory mogą być zmiennymi jakościowymi lub ilościowymi i wpływać na kierunek i (lub) siłę związku pomiędzy zmienną zależną a wybranymi jej determinantami (określać warunki, w jakich zmienne niezależne wpływają na zmienne zależne). Innymi słowy, moderator decyduje o wzroście, braku zmiany lub spadku wartości przyjmowanych przez zmienną zależną [Pichalak 2011, s. 23]. 


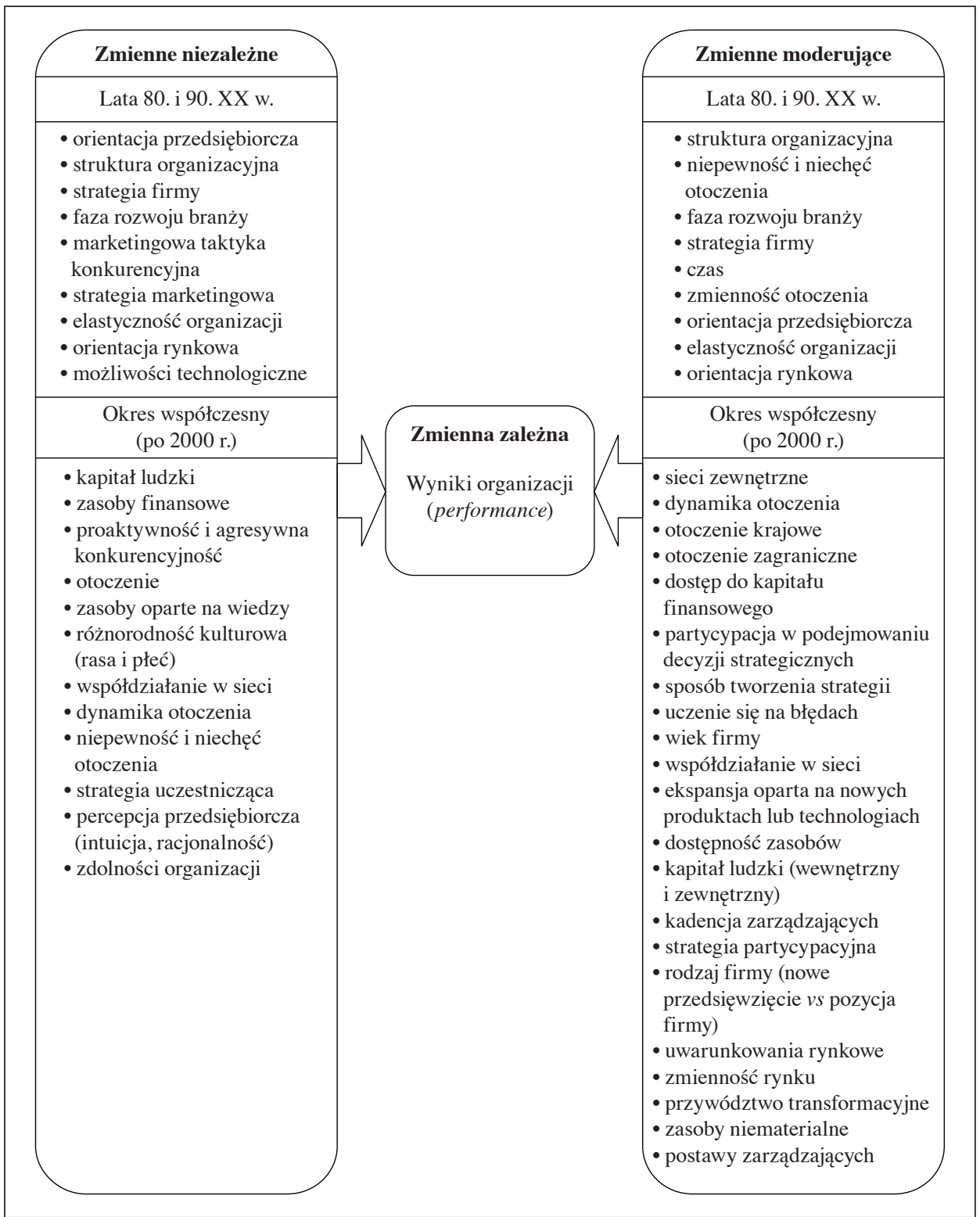

Rys. 2. Zmienne niezależne i moderujące w relacji: orientacja przedsiębiorcza a wyniki organizacji

Źródło: opracowanie własne na podstawie [Engelen et al. 2014, s. 1355-1357].

W latach 80. i 90. dwudziestego stulecia dominującą zmienną niezależną w przywoływanych badaniach stanowiła orientacja przedsiębiorcza, chociaż nie 
była ona jedynym czynnikiem, który determinował wyniki badanych organizacji. Istotne wówczas były również takie czynniki jak: struktura organizacyjna, strategia firmy, faza rozwoju branży, w której funkcjonowała firma, elastyczność organizacji, strategia marketingowa, orientacja rynkowa i możliwości technologiczne. Natomiast wśród zmiennych moderujących wpływających na wyniki osiągane przez organizacje znalazły się czas oraz niechęć i zmienność otoczenia. Ponadto były to: orientacja przedsiębiorcza, elastyczność organizacji, orientacja rynkowa, struktura organizacyjna, faza rozwoju branży i strategia firmy, które w zależności od przyjętego celu badawczego odgrywały rolę zmiennej niezależnej lub moderującej. W rezultacie ówczesnych analiz wykazano, że:

- poziom orientacji przedsiębiorczej wpływa na wyniki organizacji,

- przedsiębiorcza postawa menedżerów wpływa na wyniki organizacji oraz warunkuje kształt struktury organizacyjnej,

- firma uzyskuje korzyści z przedsiębiorczej strategii w warunkach niepewności otoczenia,

- strategia firmy różni się znacząco w zależności od fazy rozwoju branży, $\mathrm{w}$ jakiej znajduje się firma, w firmach z branży nowych technologii postawa przedsiębiorcza jest najbardziej uwydatniona,

- strategia marketingowa i orientacja przedsiębiorcza są znacząco powiązane,

- orientacja przedsiębiorcza, elastyczność i orientacja rynkowa są powiązane ze sobą i z wynikami organizacji.

W najnowszych badaniach wśród zmiennych niezależnych wyróżniono kapitał ludzki, zasoby finansowe, proaktywność i agresywną konkurencyjność, zasoby oparte na wiedzy, różnorodność kulturową, współdziałanie w sieci, dynamikę, niepewność i niechęć otoczenia oraz percepcję przedsiębiorczą (intuicja, racjonalność) i zdolności organizacji. Wśród zmiennych moderujących coraz bardziej znaczącą rolę odgrywają zasoby niematerialne i dynamiczne zdolności organizacji zorientowane na doskonalenie kapitału ludzkiego, proces uczenia się, partycypacyjny styl zarządzania, umiejętność współdziałania w sieci oraz szczególne cechy zarządzających, których postawa przedsiębiorcza determinuje wyniki organizacji. Wnioski z badań dotyczących zależności pomiędzy orientacją przedsiębiorczą a wynikami organizacji pozwoliły sformułować następujące stwierdzenia:

- poziom orientacji przedsiębiorczej nadal wpływa na wyniki organizacji;

- agresywna konkurencyjność wykazuje słabe powiązania z wynikami organizacji, okazuje się pomocna dla firm działających w branżach znajdujących się w dojrzałych fazach rozwoju;

- orientacja przedsiębiorcza wzmacnia relację między zasobami opartymi na wiedzy a wynikami organizacji;

- innowacyjność wpływa pozytywnie na relacje pomiędzy rezultatami pracy grup zróżnicowanych ze względu na rasę i płeć a wynikami organizacji; 
- orientacja przedsiębiorcza powiązana jest z wynikami organizacji, kiedy przestrzegana jest $\mathrm{w}$ firmie dyscyplina finansowa, a otoczenie ma stabilny charakter oraz wówczas, gdy proces formułowania strategii ma charakter emergentny;

- firmy starsze (dłużej istniejące na rynku) rzadziej podejmują ryzyko, co negatywnie wpływa na wyniki organizacji, młodsze firmy wykazują postawy proaktywne, co pozytywnie wpływa na wyniki;

- współdziałanie w sieci sprzyja wzmocnieniu relacji pomiędzy orientacją przedsiębiorczą a wynikami organizacji;

- relacja pomiędzy orientacją przedsiębiorczą a wynikami jest silniejsza w firmach, w których przestrzega się ustalonych procedur, identyfikowany jest wysoki poziom zaufania i zaangażowania, stosowany jest partycypacyjny styl zarządzania;

- w warunkach intensywnych zmian na rynkach, firmy o wysokim poziomie orientacji przedsiębiorczej wykazują najwyższy wzrost, zależność ta ma też odwrotny charakter;

- im bardziej zmienne otoczenie, tym wyższy poziom innowacyjności;

- wyższe poziomy zasobów niematerialnych w stosunku do konkurentów z branży pozytywnie wzmacniają relacje pomiędzy orientacją przedsiębiorczą a wynikami organizacji;

- poziom orientacji przedsiębiorczej jest istotnie powiązany z wynikami organizacji, jednak relacja ta ulega osłabieniu, gdy zarządzający ma cechy narcystyczne.

\section{Podsumowanie}

Problematyka identyfikacji orientacji przedsiębiorczej w organizacji zajmuje istotne miejsce $\mathrm{w}$ dyskursie współczesnych badaczy. Zarówno odpowiedni dobór składowych konstruktu orientacji przedsiębiorczej, jak i stopień ich intensyfikacji odgrywa zasadniczą rolę w kreowaniu strategii współczesnych organizacji. Istotne kwestie stanowią również interpretacje poszczególnych komponentów orientacji przedsiębiorczej oraz zagadnienia operacjonalizacji, stanowiące podstawę konstruowania adekwatnego narzędzia pomiaru i interpretacji rezultatów, uwzględniających specyfikę funkcjonowania danej organizacji.

Aktualny model budowania strategii opartej na orientacji przedsiębiorczej, akcentując znaczenie rozwoju zasobów niematerialnych w przedsiębiorczych działaniach organizacji, wpisuje się w trend integracji dynamicznych zdolności organizacji z teoriami przedsiębiorczości, a zwłaszcza z orientacją przedsiębiorczą. Podejście to prowadzi do analizy przedsiębiorczego zacho- 
wania, oddziaływań i efektów w płaszczyźnie łączenia zasobów i zdolności. Zachowania organizacji, a przede wszystkim jej rozwój przebiegają w ramach danego otoczenia wokół orientacji przedsiębiorczej i dynamicznych zdolności organizacji. W żywotnych spiralach rozwoju organizacji najważniejszych jest pięć wiązek zasobów: strategiczne, ludzkie, finansowe, fizyczne i organizacyjne. Rozwój organizacji ma charakter sekwencyjny i inkrementalny, a wiązki zasobów są rozbudowywane i wykorzystywane. Przewaga konkurencyjna znajduje odzwierciedlenie w związku przyczynowo-skutkowym zachodzącym pomiędzy wiązką zasobów, zdolnością dynamiczną i dającą się zaobserwować efektywnością finansową [Bratnicki 2011, s. 37]. Ponadto relacja ta warunkowana jest kreowaniem procesu uczenia się, rozwojem i przekazywaniem wiedzy, partycypacyjnym stylem zarządzania, predyspozycjami psychospołecznymi organizacji, jak również umiejętnością współdziałania w sieci, która determinowana jest innowacyjnym modelem biznesowym, stanowiącym nowe źródło przewagi konkurencyjnej.

\section{Literatura}

Anderson B.S., Kreiser P.M., Kuratko D.F., Hornsby J.S., Eshima Y. [2015], Reconceptualizing Entrepreneurial Orientation, „Strategic Management Journal”, vol. 36, nr 10, https://doi.org/10.1002/smj.2298.

Bratnicki M. [2008], Konfiguracyjne ujęcie przedsiębiorczości organizacyjnej, „Ekonomika i Organizacja Przedsiębiorstwa", nr 6.

Bratnicki M. [2011], Model przedsiębiorczego rozwoju organizacji: konstrukt i jego wymiary, „Współczesne Zarządzanie”, nr 3.

Bratnicki M., Kulikowska M. [2009], Ksztaltowanie przedsiębiorczego rozwoju w matej $i$ średniej firmie [w:] Zmiana warunkiem sukcesu. Rozwój i zmiany w matych i średnich przedsiębiorstwach, red. J. Skalik, Wydawnictwo Uniwersytetu Ekonomicznego we Wrocławiu, Wrocław.

Bratnicki M., Kulikowska-Pawlak M. [2011], Orientacja przedsiębiorcza i efektywność organizacji w kontekście strategicznych problemów rozwoju, Prace Naukowe Uniwersytetu Ekonomicznego we Wrocławiu, nr 219, Wrocław.

Covin J.G., Slevin D.P. [1989], Strategic Management of Small Firms in Hostile and Benign Environments, ,Strategic Management Journal”, vol. 10, nr 1, https://doi. org/10.1002/smj.4250100107.

Covin J.G., Wales W.J. [2012], The Measurement of Entrepreneurial Orientation, „Entrepreneurship Theory and Practice”, vol. 36, nr 4, https://doi.org/10.1111/j.15406520.2010.00432.x.

Dess G.G., Lumpkin G.T. [2005], The Role of Entrepreneurial Orientation in Stimulating Effective Corporate Entrepreneurship, „Academy of Management Executive”, vol. 19, nr 1, https://doi.org/10.5465/ame.2005.15841975.

Dyduch W. [2008], Pomiar przedsiębiorczości organizacyjnej, Prace Naukowe Akademii Ekonomicznej im. K. Adamieckiego w Katowicach, Katowice. 
Engelen A., Kube H., Schmidt S., Flatten T.Ch. [2014], Entrepreneurial Orientation in Turbulent Environments: The Moderating Role of Absorptive Capacity, „Research Policy", vol. 43, nr 8, https://doi.org/10.1016/j.respol.2014.03.002.

Głód W. [2012], Strategie umiędzynarodowienia MSP i ich uwarunkowania - wyniki badań [w:] Strategie rozwoju organizacji, red. A. Stabryła, T. Małkus, Mfiles, Kraków.

Hughes M., Morgan R.E. [2007], Deconstructing the Relationship between Entrepreneurial Orientation and Business Performance at the Embryonic Stage of Firm Growth, „Industrial Marketing Management”, vol. 36, nr 5, https://doi.org/10.1016/ j.indmarman.2006.04.003.

Kreiser P.M., Marino L.D., Weaver K.M. [2002], Assessing the Psychometric Properties of the Entrepreneurial Orientation Scale: A Multi-country Analysis, „Entrepreneurship Theory and Practice", vol. 26, nr 4.

Lumpkin G.T., Dess G.G. [1996], Clarifying the Entrepreneurial Orientation Construct and Linking It to Performance, ,Academy of Management Review”, vol. 21, nr 1, https://doi.org/10.5465/amr.1996.9602161568.

Lyon D.W., Lumpkin G.T., Dess G.G. [2000], Enhancing Entrepreneurial Orientation Research: Operationalizing and Measuring a Key Strategic Decision Making Process, „Journal of Management”, vol 26, nr 5.

Miller D. [1983], The Correlates of Entrepreneurship in Three Types of Firms, „Management Science", vol. 29, nr 1, https://doi.org/10.1287/mnsc.29.7.770.

Nogalski B., Karpacz J. [2011], Komponenty orientacji przedsiębiorczej-studium przypadku, „Współczesne Zarządzanie”, nr 3.

Pearce J.A., Fritz P., Davis P.S. [2010], Entrepreneurial Orientation and the Performance of Religious Congregations as Predicted by Rational Choice Theory, „Entrepreneurship Theory and Practice”, vol. 34, nr 1, https://doi.org/10.1111/j.15406520.2009.00315.x.

Pichalak M. [2011], Moderatory i mediatory innowacyjności organizacji, „Współczesne Zarządzanie", nr 4.

Wiklund J. [1999], The Sustainability of Entrepreneurial Orientation - Performance Relationship, „Entrepreneurship Theory \& Practice”, nr 1.

Wiklund J., Shepherd D. [2005], Entrepreneurial Orientation and Small Business Performance: A Configurational Approach, „Journal of Business Venturing”, vol. 20, nr 1, https://doi.org/10.1016/j.jbusvent.2004.01.001.

Zahra S.A., Neubaum D.O. [1998], Enviromental Diversity and the Entrepreneurial Activities of New Ventures, ,Journal of Developmental Entrepreneurship”, vol. 3, nr 2.

Zbierowski P. [2012], Orientacja pozytywna organizacji wysokiej efektywności, Oficyna a Wolters Kluwer Business, Warszawa.

Ziębicki B. [2011], Istota i ewolucja koncepcji Performance Management (zarzadzanie wynikami) [w:] Rozwój koncepcji i metod zarządzania, red. J. Czekaj, M. Lisiński, Fundacja Uniwersytetu Ekonomicznego w Krakowie, Kraków. 


\section{Methodological Aspects of the Assessment of Entrepreneurial Orientation in Organisations \\ (Abstract)}

The study presents the methodological aspects of evaluating entrepreneurial orientation in the organisation. The assumptions behind and the essence of the concept of entrepreneurial orientation are presented. The components of entrepreneurial orientation - innovativeness, being proactive, taking risks, autonomy, competitive aggressiveness are characterised. Guidelines and tools for and the problems that may be encountered in measuring the orientation of entrepreneurial organisation are introduced. The study also presents the results of multifaceted research into how the relationship between entrepreneurial orientation and the results an organisation produces is shaped, based on a review of the foreign literature on the subject. It also shows the need for a widened examination perspective of that relationship, and emphasises the importance of the organisation's intangible resources and dynamic abilities in developing strategy.

Keywords: corporate entrepreneurship, entrepreneurial orientation, measurement of entrepreneurial orientation, the relationship between entrepreneurial orientation and organisational performance. 